\title{
Property Rights in Albania: Historical Background and Current Issues
}

\author{
Phd. Adrian Leka \\ Faculty of Law, "Luigj Gurakuqi" Universitety \\ Email: leka-ad@live.com
}

\section{Doi:10.5901/ajis.2016.v5n3s1p327}

\section{Abstract}

Dismemberment of the communist system in Albania as the ideological aspect as well as in the economic, and the transfer of land in the difficult period of transition to a market economy and the consolidation of democracy was accompanied by the birth and development of a series of economic and social phenomena, which related to the demographic movement of people from rural to urban areas. Similarly, the construction sector experienced rapid development, but fast paced growth could not be controlled by the legal framework inherited from the communist regime.Effective legislation proved to be insufficient to be applied quickly and effectivelyto control this important sector that was excessively complicated by bringing heavy distortion due to urban development of cities. The phenomenon of informality in construction today affects the whole territory of the Republic of Albania and focuses mainly in suburban areas. Immovable property represents in the Republic of Albania today a special interest in relation to social economic and political developments that our country is going through. The right of ownership is accepted by society and the system in which we live because of fundamental importance, acceptance of private property is not done verbally, but it is sanctioned in the most important document of the state, in the Constitution of the Republic of Albania.To put in writing indicates willingness to respect this right, to guarantee the safety and protection.In order to exercise the right of private property in practice, the individual must own a private property recognized as such.Immovable property represents in the Republic of Albania a special interest in relation to social economic and political developments that our country is going through. The right of ownership is accepted by society and the system in which we live.Due to the fundamental importance of the acceptance of private property is not done verbally, but is written in the most important document of the state, in the Constitution. To put in writing indicates willingness to respect this right, to guarantee the safety and protection.In order to exercise the right of private property in practice, the individual must own a private property recognized as such. Our previous system considered all property as common property ie anyone's or everyone's. If private property is not recognized by the Constitution and is not reflected in other laws, its absence allows and encourages theft, misuse of property and creates obstacles for the development of the country.

\section{Property along the Existence of the Albanian State. The Period from 1912-1945}

After the declaration of independence and the creation of a genuine Albanian state freely and independently for the first time, it was necessary the creation and restructuring of state institutions through the issuance of laws for this purpose.The functioning and organization of the state firstly as a republic and then as a monarchy will be characterized by the revival of the system of law in Albania.So the government of Ismail Qemali although made some changes and legal regulations in some respects, left in force temporarily until the issue of a new law, the laws that existed during the Ottoman occupation where one of these laws which continued to exist was the legal regime of land until 1925 was governed by the law of the land to the year $1856^{1}$ [Dudaj,Tirane 2010].An important step represents the Civil Code of Albanian Kingdom which entered into force on 1 April 1929 and gave a full and difinitive understanding to property and considered it as sacred and inviolable. The basis of this code wasthe limited private ownership of which relied on the right to the enjoyment and possessed items without restrictions, being guaranteed and enshrined by law. These would be the first legal acts that will cast the bases of a progressive legal system.1939 marked the end of a long period where Albanian state ceased to exist as a sovereign state.This year was the end of the first conquest of Italy and then Germany, where this period would disperse and would limit a series of rights of political, social, economic that were born and were strengthened before the invasion of the country.

\subsection{The period after 1945.}

During 1945-1990 the Albanian state set a new regime, previously untried, which was formally advertised as a mode of working class and protecting its interests but in reality from the moment it was set up until its overthrow reality spoke to 
the contrary. This new popular regime came as a progressive stream to the spirit of communist ideas, which meant that every citizen of the working class would not feel oppressed and inferior by the wealthy class.On the basis of these utopian ideas for the state during the years 1945-1990 would be led by an oligarchy institutionalized individuals whom in Albania not only the welfare, but also the health of citizens, but the dictatorship of the proletariat thus undermining any economic freedom, political and social which were placed before 1939. Thus the state guaranteed the prices, but did not guarantee citizens' needs for accommodation, goods, services and other vital needs ${ }^{2}$ [V.Duka,History of Albania 19122000]. This was the time when it was removed the right of private ownership and became expropriation of buildings constructed by violating every right of the individual as owner.Expropriations made by the regime were not the same for all categories, as they were made according to a specific plan by the regime itself in order to have everything in control.

\subsection{The situation of the property in 1989 .}

In 1989 all Albanian lands were owned by the state. The principle of exclusive state ownership was sanctioned in the Constitution of $1976^{3}$ [See Constitution of the People's of Albania], this was the final legal action to prohibit any other form of collective rights or private property in land.By the end of the 80s, there was a broad opinion that the economy was in crisis. The causes are found in a series of distorted economic policies, but strict control of land was an important element, especially for the agricultural crisis.Ministry of Agriculture and Food has explained the political and economic origins of the land reform in this way ${ }^{4}$ [World Bank,Report of 1992] 1990 agriculture constituted deficiencies in the national economic system. While it constituted $52 \%$ of GDP and employed $54 \%$ of the total national labor force, the government drew profit from the production of farm but gave back a very small portion as payment and investment. When rural population was growing at $3 \%$ per annum; agricultural output grew by only $0.03 \%$ as a result of low financemnet and lack of investment. "Legislative change came in 1991, when under conditions of crisis, the parliament adopted the law on the Constitutional principles of 1991, which rejected the Constitution of 1976 and served as the basic law until the drafting of the new constitution of 1998. The law referred to private ownership of land and forced the state to develop economic relations based on market principles. He would force the Parliament and the Government to review the structure of ownership of land and real estate in Albania.

\section{Steps Towards Recognizing and Sanctioning Private Property. The Period after 90s}

The overthrow of the dictatorship and establishing democracy pitted Albanian state and society to a large number of challenges and reforms that had to be overcome.The transition from a system where the government was the sole owner in a system where there is private property demanded not only a legal, economic and institutional reform but demanded that people foremost radically change their concept for the property ${ }^{5}$ [Juliana Latifi, Set of lectures UET]. One of the key reforms that were undertaken in this period was the adoption of the law the No. 7491 dated 04.1991 " for major Constitutional provisions " by means of which was abrogated the 1976 Constitution.In Article 11 of Law no. 7491 is expressed " subject to the right of ownership are state, legal and physical persons'.All kinds of ownership enjoy equal protection by the state. With the repeal of the 1976 Constitution the state has lost the right to be the sole owner of land in the Republic of Albania.In 1991 the Albanian government started land reform and immovable property relations by improving the existing Civil Code (1981), authorizing transactions ranging market and transfer of agricultural, residential and commercial property in the ownership of citizens and legal persons.

\subsection{The first laws for the distribution of land and property privatization.}

Three new laws adopted in 1991-1992, started programs transfer ownership rights on land and real estate from the state to citizens and legal persons. These laws included a mix of elements defining the relationships of people with the tangible objects of immovable entitlements and land. Some elements were held by the communist period were taken by other European civil codes.Law No. 7501, For the Landauthorized under the allocation and transfer of land to family members of the collective farms in equal parts.Law No.7501 date 19/07/1991 "For the Land" was the first time that we would sanction the right of the individual to the land. Object of the law is above all land and agricultural land. Article 1 of this law characterizes the land:

- Agricultural land

- $\quad$ Land occupied by forests, pastures and meadows.

- Agricultural land (land not included in the above two points) 
Following the law sanctions that the land can not be exclusive of the state, as this gives you the land natural and legal persons who exercise the right of ownership or other rights would be recognized in that law.One such right is the right of use. This legal transaction of agricultural land from the state to local natural or legal person is done without compensation. Unlike their foreign domestic entities may be granted only land to use for rent. The law makes a detailed arrangement of transfer of agricultural land to a private entity can be classified as:

- Member of the families partakers on agricultural cooperative.

- Member of the families residing in the village, but that has not been a member of the agricultural cooperative.

- Member of the families living and working in agricultural enterprises.

Regarding the right of members of a farming family to be treated with agricultural land under Law 7501 " For the Land " and the obligation of the Commission of land in the village and the municipality to address the request of the parties concerned, This kind of relationship has been part of the unifying practice of the United Chambers of the Supreme Court.

\section{Property Restitution and Compensation of Former Owners}

Regulating the issue of property after communism is different from other ownership changes made throughout history. This is comparable with the nationalization of all industries (eg mining) or secular church property.lt is comparable only to the process of establishing socialist collective ownershipwhich aimed total liquidation of private property. The return of private property and a market economy in the former socialist countries is an extraordinary historical process. The first law on property restitution and compensation belongs to 1993, its adoption was accompanied by controversy and a great debate both public and legal. The issue was discussed with the debate on the return of farmland that began in 1993 when the original law no. 7698, for the return of property to the former owners. In the framework of the Constitution the new Law no. 9235 dated 29.07.2004 was drafted for property restitution and compensation. The new law, that of 2004, for property restitution and compensation of several problems of the law of 1993.It had the same initial order, restitution and compensation of immovable property expropriated, nationalized or confiscated during November 1944. This law recognizes a wider number of complaints and plaintiffs that the previous law but continues to exclude agricultural lands that are subject to the Law no. 7501.To determine the degree of restitution / compensation court was based on the market value and the other hand to apply this method of evaluation court requires two conditions:

- First to show that in determining the suitability of a particular act by a country that had to do with issues of land and property any interference in the exercise of these rights should establish a fair balance between the aim sought to be achieved and the nature of the act.

- Second, each pretender for restitution or compensation should have the right to an independent court, impartial that will determine his complaints rapidly and effectively.

\section{Conclusions}

From all panorama presented above, I can say unequivocally about the history of relations on the ownership role of the state in this regard, other problems that have accompanied the processes of control and administration of the territory, Albania constitutes a special occasion.Seeing the drastic measures taken by the regime communist for nationalization total ownership, abrogation of the existing legislation on property, validation of concepts communist on joint property and the administration of the territory, and implement radical reforms aimed expropriation mass of owners worsened in a sensitive way the welfare level of the population and negatively affected the country in the development of Economics.Dismemberment of the communist system in Albania, as in the ideological aspect as well as in the economic, and the transfer of land in the difficult period of transition to a market economy and the consolidation of democracy was accompanied by the birth and development of a series of economic and social phenomena, which related to the demographic movement of people from rural to urban areas.Also rapid developments were happening in the construction sector in Albania but rising fast paced could not be controlled from the legal framework inherited from the communist regime, the legislation in force proved to be insufficient to be applied quickly and effectively to control this important sector that was greatly complicated bringing heavy distortion due to urban development of cities. The phenomenon of informality in construction affects the whole territory of the Republic of Albania with focuses mainly in suburban areas.Continuing delays in resolving the issue of compensation and restitution caused a circular dilemma, prevented the land and property rights in many areas.In one side location and boundaries of state property can not be clearly defined until turned parcels and private plots would be defined.On the other side, until state properties were determined it was 
impossible to foresee what would be the alternative ground.Lack of information on the alternatives and values compel the former owners to choose between continuing their complaints and receive compensation. The principle of return and compensation for families whose property was confiscated during the Communist era, was added in the Albanian law 1993 because land distribution programs for farmers, villagers and privatization of apartments were being conducted.So laws must resolve claims conflicts between new owners (those who won their rights under the post-privatization legislation of 1991) and the former owners.

\section{References}

Galgano Francesco, "Private Law", Luarasi University, Tirana 2006.

Agency for the Legalization, Urbanization and Integration of Informal Areas, Meeting with the donors 1.Year 2009.

Juliana Latifi, Set of lectures, The ownership, UET.

Arben Puto, Political Albania (1912-1939).

Ardian Nuni, "Lectures of the right of ownership" Tirana 2002.

History of Albania and the law in Albania, Luarasi, Tirana.

Constitution of the Republic of Albania.

The 1994 Civil Code.

The 1929 Civil Code. 